\title{
NUTRIENT COMPOSITION OF NIGER SEED (GUIZOTIA ABYSSINICA (L. f.) CASS.) CULTIVATED IN DIFFERENT PARTS OF ETHIOPIA
}

\author{
Matiwes Syume and Bhagwan Singh Chandravanshi* \\ Department of Chemistry, Addis Ababa University, P. O. Box 1176, Addis Ababa, Ethiopia
}

(Received September 2, 2014; revised August 31, 2015)

\begin{abstract}
The levels of essential and non-essential metals in niger seed (Guizotia abyssinica (L. f.) Cass.) cultivated in different parts of Ethiopia were determined by flame atomic absorption spectrometry after wet digestion using $2.5 \mathrm{~mL}$ of $\mathrm{HNO}_{3}(69.5 \%), 1 \mathrm{~mL} \mathrm{HClO} 4(60 \%)$ and $0.5 \mathrm{~mL}$ of $30 \% \mathrm{H}_{2} \mathrm{O}_{2}$ at $210{ }^{\circ} \mathrm{C}$ for $150 \mathrm{~min}$. Sampling was carried out randomly from nine different sites from Ethiopia and one sample from Eretria for comparison. The following metal concentration ranges $(\mu \mathrm{g} / \mathrm{g})$ were determined in niger seed samples, respectively: $\mathrm{Na}(159-736), \mathrm{K}$ (5594-8203), Ca (340-680), Mg (2404-4656), Mn (13.4-34.3), Fe (31.6-370), Cu (9.5-61.2), Zn (23.4-46.2), Cr (4.0-16.8), Co (4.9-27.3), Ni (13.0-32.4), Pb (15.5-19.3) and Cd was not detected in all the samples. The analysis of variance indicated the presence of significance difference at $95 \%$ confidence level among niger seeds collected from different sites. Pearson correlation coefficients indicated that there were significant correlations among some metals in the niger seed. The study revealed that niger seed is good source of essential metals and free from toxic metal such as Cd and hence safe for human consumption. Generally, the metal concentration in niger seed is comparable with other oil seeds.
\end{abstract}

KEY WORDS: Niger seed, Guizotia abyssinica, Nutrient, Metal, Ethiopia

\section{INTRODUCTION}

Oilseeds are a mainstay of the rural and national economy in Ethiopia. After coffee, oilseeds are the second largest export earner for the country and more than 3 million smallholders are involved in its production. Exports of the country consist of sesame and niger seed [1] to different countries in the world.

Niger is an oilseed crop mainly cultivated in different parts of Ethiopia and India. It constitutes about $50 \%$ of the Ethiopian and 3\% of Indian oilseed production. The two countries are the first and second niger seed producers and users in the world, respectively. In Ethiopia, it is cultivated on waterlogged soils where most crops and all other oilseeds fail to grow and contributes a great deal to soil conservation and land rehabilitation. Niger is a crop of the cooler parts of the tropics. It is being cultivated in many countries of tropical and temperate zones. Ethiopia and India are the major niger seed producing countries of the world [2]. It is also minor oil crop in India, Kenya, Uganda, Sudan, Malawi and other African countries [3, 4]. The major niger producing areas in Ethiopia are characterized by moderate temperatures ranged between $16{ }^{\circ} \mathrm{C}$ and $20{ }^{\circ} \mathrm{C}$ during the growing season. In Ethiopia, niger is cultivated at altitudes ranging from $500 \mathrm{~m}$ to $2980 \mathrm{~m}$ but mainly grown in mid-altitude and highland areas (1700-2200 m). It grows well in areas where rainfall is 1000 to $1300 \mathrm{~mm}$ per year [5].

The niger plant is consumed by sheep but not by cattle, to which only niger silage can be fed [6]. Moreover, niger is used as a green manure for increasing soil organic matter [5]. Niger seed is the most important oil crop in Ethiopia and a minor crop in India but it is not involved in the world-wide oilseed trade rather than used as bird feed. Besides cookery, niger seed oil can be used in the manufacture of soap, paints, or as a lubricant or illuminant. The protein-rich meal which remains after oil extraction is used as animal feed, manure or fuel [7]. In addition to its oil, the crop offers an important source of seed protein [8] that significantly contributes to the human dietary protein intake [9]. The oil of niger seeds appears to be nutritionally valuable, as

\footnotetext{
*Corresponding author. E-mail: bscv2006@yahoo.com
} 
the high content of linoleic acid is known to prevent cardiovascular diseases and to be the precursor of structural components of plasma membranes and of some metabolic regulatory compounds [10]. Additionally, it is accompanied by a significant antioxidant activity, mainly due to sterols and tocopherols [11].

The niger seed contains up to $40 \%$ edible semidrying oil, $20.9 \%$ carbohydrate and $27.8 \%$ protein [3-5]. Niger meal remaining after the extraction of oil contains approximately $30 \%$ protein and $23 \%$ crude fiber. The oil, protein and crude fiber contents of niger seeds are affected by the hull thickness and thick-hulled seeds tend to have less oil and protein and more crude fiber. Niger oil has a fatty acid composition typical for seed oils of the Asteraceae plant family (for example, safflower and sunflower) with linoleic acid being the dominant fatty acid. The linoleic acid content of niger oil was approximately 55\% in seed grown in India [12] and $75 \%$ in seed grown in Ethiopia [13, 14]. In general, the Ethiopian niger meal contains less protein and more crude fiber than the niger meal grown in India [6, 13]. Dutta et al. [11] reported 29$39 \%$ oil in niger seed collected from different regions of Ethiopia, while Almaw and Teklewold [14] reported the oil content as ranged from 39.8-46.9\%. Seegeler [13] reported oil contents of $30-50 \%$. Other than being very important for their nutritional value, oilseeds have considerable importance for industrial and pharmaceutical purposes [7].

Recently, trace elements and heavy metal contents in some spices and herbs widely cultivated and consumed in Ethiopia has been determined. These studies include levels of selected metals in the leaves of different species of thyme (Thymus schimperi and Thymus vulgaris) [15], metallic nutrients in enset (Ensete ventricosum) corm [16], levels of major and trace metals in onion (Allium cepa L.) [17], levels of metals in vegetables [18], levels of essential and non-essential metals in Rhamnus prinoides (Gesho) [19], mineral composition of sorghum landrace accessions from Ethiopia [20], mineral contents of fruits of cactus pear (Opuntia ficus indica) [21] and levels of major, minor and toxic metals in tubers and flour of Dioscorea abyssinica [22]. Mineral contents of seed and seed oils of Capparis species growing wild in Turkey have been report during last year [23]. Levels of essential and non-essential metals in linseed (linum usitatissimum) cultivated in Ethiopia have also been reported during last year [24].

However, there is no report in literature about the metal content of niger seed which is consumed in Ethiopia and other countries. The purpose of this study was to determine the concentration and distribution of major, minor and toxic elements in niger seeds grown in Ethiopia and Eretria. The study was also aimed to assess the role of niger seeds as sources of essential nutrition.

\section{EXPERIMENTAL}

\section{Chemicals and reagents}

$\mathrm{HNO}_{3}\left(69.5 \%\right.$, Scharlau, European Union), $\mathrm{HClO}_{4}\left(60 \%\right.$, BDH, England) and $\mathrm{H}_{2} \mathrm{O}_{2}(30 \%$, Scharlau, European Union) were used for digestion of samples for metal determination. Lanthanum nitrate hydrate (BDH, England) was used to avoid refractory interference (for releasing calcium and magnesium from their phosphates). Standard solution of concentration $1000 \mathrm{mg} / \mathrm{L}$ in $2 \% \mathrm{HNO}_{3}$ of the metals such as, $\mathrm{Na}, \mathrm{K}, \mathrm{Ca}, \mathrm{Mg}, \mathrm{Mn}, \mathrm{Cu}, \mathrm{Zn}, \mathrm{Co}, \mathrm{Cr}, \mathrm{Fe}$ and $\mathrm{Ni}$ as nitrate salt were used for calibration standard and spiking experiment.

\section{Instrumentation}

Flame atomic absorption spectrophotometer (Buck Scientific Model 210VGP AAS, East Norwalk, USA) equipped with deuterium arc back ground correctors and hollow cathode lamps with air-acetylene flame was used for the analysis of the analyte metals in niger seed. Kjeldahl digestion apparatus (Gallenkamp, England) fitted with round bottomed flask and reflux 
condenser was used for digestion of powdered niger seed samples. A drying oven (Digitheat, Spain) was used for evaporation and dryness of niger seed samples. A refrigerator (Hitachi, Japan) was used for the preservation of digested samples before AAS analysis was made.

\section{Description of the sampling areas}

Niger seeds were collected from different parts of Ethiopia and Eretria (Figure 1). The samples sites were the major niger seed production areas in Ethiopia and for comparison Eretria were used. The sites were also selected based on different parameters such as different rainfall level, altitude, soil fertility and climate condition. The samples were collected from Jimma, Debre Markos, Kombolcha, Mekelle, Gondar, Debre Birhan, Awi Zone and Alamata. While Wellega samples were collected from Ethiopian biodiversity institution which had twelve different sites and were mixed together as Wellega sample. Eritrean samples were also collected from Ethiopian biodiversity institution which had ten accessions. The samples other than Eretria and Wellega were collected from the source (production area) which was grown in 2012. The sample sites and their location are given in Table 1.

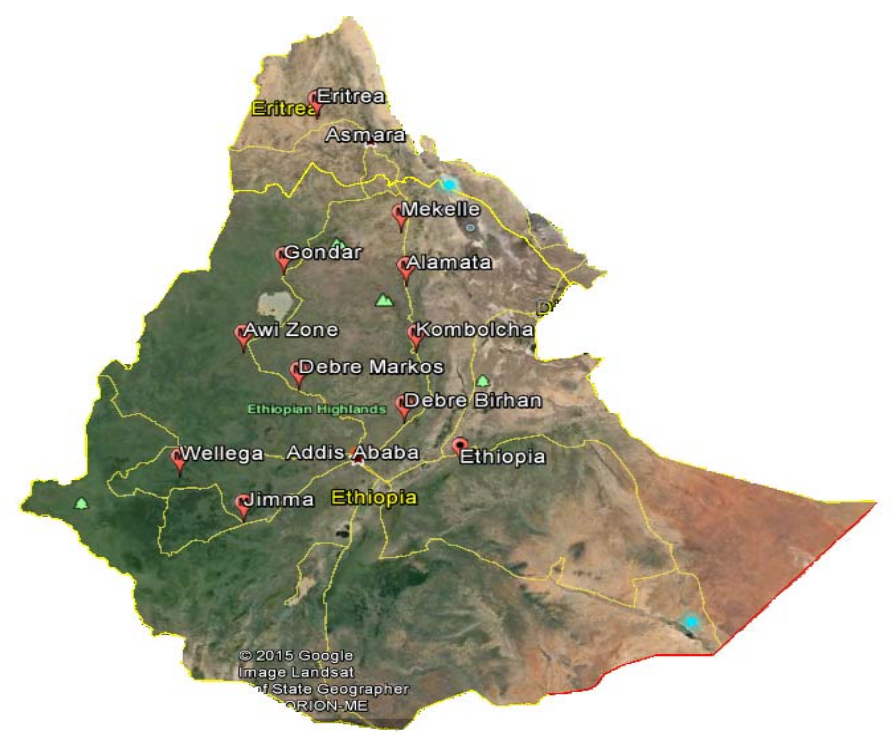

Figure 1. Map showing niger seed sampling sites in Ethiopia and Eritrea.

Table 1. The regions and locations of sampling sites.

\begin{tabular}{|l|c|c|c|}
\hline Sample site & Region & Latitude & Longitude \\
\hline Jimma & Oromia & $07-40-00-\mathrm{N}$ & $36-50-00-\mathrm{E}$ \\
\hline Debre Markos & Amhara & $100-21-00-\mathrm{N}$ & $370-23-00-\mathrm{E}$ \\
\hline Kombolcha & Amhara & $11-05-00-\mathrm{N}$ & $39-44-00-\mathrm{E}$ \\
\hline Mekelle & Tigray & $13-29-00-\mathrm{N}$ & $39-28-00-\mathrm{E}$ \\
\hline Gondar & Amhara & $12-36-00-\mathrm{N}$ & $37-28-00-\mathrm{E}$ \\
\hline Debre Birhan & Amhara & $09-41-00-\mathrm{N}$ & $39-32-00-\mathrm{E}$ \\
\hline Awi Zone & Amhara & $10-05-00-\mathrm{N}$ & $36-47-00-\mathrm{E}$ \\
\hline Alamata & Tigray & $12-20-00-\mathrm{N}$ & $39-30-00-\mathrm{E}$ \\
\hline Wellega & Oromia & $08-35-00-\mathrm{N}$ & $35-43-00-\mathrm{E}$ \\
\hline Eritrea & Eritrea & $15-46-84-\mathrm{N}$ & $37-59-20-\mathrm{E}$ \\
\hline
\end{tabular}

Bull. Chem. Soc. Ethiop. 2015, 29(3) 
Sample collection

Niger seed samples were collected from the production area from three different places for each site except Wellega and Eretria. Half a kilo niger seeds from each places were mixed together in a polyethylene bag, labeled and brought to the laboratory for further pretreatments, the same was done for all the eight samples. Twelve accessions from Wellega and ten from Eretria were collected from the Gene Bank. A three gram sample (one full pack) from each accession was mixed in a polyethylene bag, labeled and brought to the laboratory for further pretreatments.

\section{Sample preparation for metals determination}

The niger seed samples collected from the ten sampling areas were sieved through a polyethylene sieve to remove large debris, stones, and pebbles. The sieved samples were washed two times with tap water and rinsed with deionized water three times to remove soil from the seed and were dried in the sun light until dried. The dried samples were ground with blander and sieved with $1.4 \mathrm{~mm}$ polyethylene sieve.

Half $g$ of dried, powdered and homogenized niger seed samples were transferred into a 100 $\mathrm{mL}$ round bottomed flask. To this $2.5 \mathrm{~mL}$ of $\mathrm{HNO}_{3}(69.5 \%)$, followed by $1 \mathrm{~mL} \mathrm{HClO}_{4}(60 \%)$ and $0.5 \mathrm{~mL}$ of $30 \% \mathrm{H}_{2} \mathrm{O}_{2}$ were added and the mixture was digested on a Kjeldahl digestion apparatus (Gallenkamp, England) fitting the flask to a reflux condenser by setting the temperature first to dial at $1\left(30^{\circ} \mathrm{C}\right)$ for the first $10 \mathrm{~min}$ and raised to dial $2\left(60{ }^{\circ} \mathrm{C}\right)$ for the next $10 \mathrm{~min}$ then raised to dial at $4\left(120^{\circ} \mathrm{C}\right)$ for the next $10 \mathrm{~min}$. Finally raised to dial $7\left(210^{\circ} \mathrm{C}\right)$ for the remaining $110 \mathrm{~min}$. The digest was allowed to cool to room temperature for $30 \mathrm{~min}$ without dismantling the condenser from the flask and for $30 \mathrm{~min}$ after removing the condenser. To the cooled solution $10 \mathrm{~mL}$ of deionized water was added to dissolve the precipitate formed on cooling and to minimized dissolution of filter paper by the digest residue while filtering with Whatman, (70 mm, diameter). The folded filter was put on the plastic funnel fitted with $50 \mathrm{~mL}$ volumetric. The round bottom flask was rinsed subsequently with deionized water until the total volume reached around $45 \mathrm{~mL}$. To this final solution, $2 \mathrm{~mL}$ lanthanum nitrate solution $(1 \%$ $\mathrm{w} / \mathrm{w})$ was added and the solution was filled to the mark $(50 \mathrm{~mL})$ with deionized water. The digestion was carried out in triplicate for each bulk samples. Digestion of triplicate reagent blanks were also performed in parallel with the niger seed samples keeping all digestion parameters the same.

Major, trace and toxic metal determination in niger seed

Four standard solutions for each metal ( $\mathrm{Na}, \mathrm{K}, \mathrm{Ca}, \mathrm{Mg}, \mathrm{Mn}, \mathrm{Fe}, \mathrm{Cu}, \mathrm{Zn}, \mathrm{Cr}, \mathrm{Co}, \mathrm{Ni}, \mathrm{Cd}$ and $\mathrm{Pb}$ ) were prepared from stock solution $(1000 \mathrm{mg} / \mathrm{L})$. Flame atomic absorption spectrophotometer, FAAS, equipped with deuterium arc background corrector and standard air-acetylene flame system using external calibration curve after optimizing the parameters in to maximum signal intensity of the instrument was used for determination of metal of interest. All the metals were determined by absorption/concentration mode and the instrument readout was recorded for each solution manually. Triplicate samples, six blank samples and four working standards for each metal were determined under the same conditions. The analytical wavelengths, method detection limits, correlation coefficients of the calibration curves and the correlation equations are given in Table 2 .

\section{Method detection limit}

Method detection limit (MDL) is defined as minimum concentration of a substance (in a given matrix) that can be measured with $99 \%$ confidence that the analyte concentration is greater than 
zero, and is determined from analysis of a sample in a given matrix containing the analyte. In this study, six blank samples were used and pooled standard deviation was calculated. Method detection limit was calculated by multiply pooled standard deviation of blank sample by three. Result below method detection limit was not reported. The method detection limits (Table 2) clearly indicate that the selected metals can be determined at trace labels in the niger seed.

Table 2. The analytical wavelengths, method detection limits, correlation coefficients of the calibration curves and the correlation equations for determination of metals in niger seed samples by FAAS.

\begin{tabular}{|c|c|c|c|l|}
\hline Metal & $\begin{array}{c}\text { Wavelength } \\
(\mathrm{nm})\end{array}$ & $\begin{array}{c}* \mathrm{MDL} \\
(\mu \mathrm{g} / \mathrm{g})\end{array}$ & $\begin{array}{c}\text { Correlation } \\
\text { coefficient }\end{array}$ & Equation of calibration curve \\
\hline $\mathrm{Na}$ & 589.0 & 10 & 0.9999 & $\mathrm{Y}=0.0014 \times 10^{-4}+0.0729 * \mathrm{X}$ \\
\hline $\mathrm{K}$ & 766.5 & 9.0 & 0.9998 & $\mathrm{Y}=-5.32 \times 10^{-6}+0.00618^{*} \mathrm{X}$ \\
\hline $\mathrm{Ca}$ & 422.7 & 3.0 & 0.9999 & $\mathrm{Y}=-7.04 \times 10^{-5}+0.00266^{*} \mathrm{X}$ \\
\hline $\mathrm{Mg}$ & 285.2 & 5.0 & 0.9999 & $\mathrm{Y}=0.0017 \times 10^{-4}+0.186^{*} \mathrm{X}$ \\
\hline $\mathrm{Mn}$ & 279.5 & 1.1 & 0.9999 & $\mathrm{Y}=6.52 \times 10^{-7}+0.024 * \mathrm{X}$ \\
\hline $\mathrm{Fe}$ & 248.3 & 4.2 & 0.9999 & $\mathrm{Y}=7.15 \times 10^{-5}+0.00411^{*} \mathrm{X}$ \\
\hline $\mathrm{Cu}$ & 324.7 & 3.0 & 0.9996 & $\mathrm{Y}=-6.76 \times 10^{-5}+0.0113^{*} \mathrm{X}$ \\
\hline $\mathrm{Zn}$ & 213.9 & 9.0 & 0.9999 & $\mathrm{Y}=-1.70 \times 10^{-5}+0.116^{*} \mathrm{X}$ \\
\hline $\mathrm{Cr}$ & 357.9 & 5.6 & 0.9993 & $\mathrm{Y}=4.18 \times 10^{-4}+0.0101 * \mathrm{X}$ \\
\hline $\mathrm{Co}$ & 240.7 & 6.0 & 0.9999 & $\mathrm{Y}=6.35 \times 10^{-5}+0.00341 * \mathrm{X}$ \\
\hline $\mathrm{Ni}$ & 232.0 & 6.0 & 0.9999 & $\mathrm{Y}=-2.48 \times 10^{-5}+0.00697 * \mathrm{X}$ \\
\hline $\mathrm{Cd}$ & 228.9 & 6.0 & 0.9999 & $\mathrm{Y}=6.27 \times 10^{-4}+0.06712 * \mathrm{X}$ \\
\hline $\mathrm{Pb}$ & 283.2 & 13 & 0.9999 & $\mathrm{Y}=-5.30 \times 10^{-5}+0.00312 * \mathrm{X}$ \\
\hline
\end{tabular}

*MDL $=$ Method detection limit.

\section{Method validation for metal determination}

The method validation for metal analysis was done by spiking experiment. Niger seed sample spiking was done by adding, $43 \mu \mathrm{L}$ of $1000 \mathrm{mg} / \mathrm{L} \mathrm{Na}, 570 \mu \mathrm{L}$ of $1000 \mathrm{mg} / \mathrm{L} \mathrm{K}, 42 \mu \mathrm{L}$ of 1000 $\mathrm{mg} / \mathrm{L} \mathrm{Ca}, 275 \mu \mathrm{L}$ of $1000 \mathrm{mg} / \mathrm{L} \mathrm{Mg}, 30 \mu \mathrm{L}$ of $100 \mathrm{mg} / \mathrm{L} \mathrm{Mn}, 14 \mu \mathrm{L}$ of $1000 \mathrm{mg} / \mathrm{L} \mathrm{Fe}, 55 \mu \mathrm{L}$ of $100 \mathrm{mg} / \mathrm{L} \mathrm{Cu}, 35 \mu \mathrm{L}$ of $100 \mathrm{mg} / \mathrm{L} \mathrm{Zn}, 10 \mu \mathrm{L}$ of $100 \mathrm{mg} / \mathrm{L} \mathrm{Cr}, 10 \mu \mathrm{L}$ of $100 \mathrm{mg} / \mathrm{L} \mathrm{Co}, 35 \mu \mathrm{L}$ of $100 \mathrm{mg} / \mathrm{L} \mathrm{Ni}, 5 \mu \mathrm{L}$ of $10 \mathrm{mg} / \mathrm{L} \mathrm{Cd}$ and $20 \mu \mathrm{L}$ of $100 \mathrm{mg} / \mathrm{L} \mathrm{Pb}$ standard solution to $100 \mathrm{~mL}$ round bottomed flask containing $0.5 \mathrm{~g}$ niger seed sample. The spiked and non-spiked (as blank during recovery test) sample were digested with similar condition within triplicate.

\section{RESULTS AND DISCUSSION}

\section{Optimization of digestion of niger seed sample}

During digestion, four parameters (composition of reagents, volume of reagents, temperature and time) were adjusted to make the niger seed sample free from organic matter and to get the metal ion in free form. The one which produces clear and colorless solution within minimum amount of reagent proportion, time and temperature was selected.

Volumes of reagents $\left(\mathrm{HNO}_{3}, \mathrm{H}_{2} \mathrm{O}_{2}\right.$ and $\left.\mathrm{HClO}_{4}\right)$ were optimized first by varying the proportion of the reagents within constant temperature $\left(270{ }^{\circ} \mathrm{C}\right)$ and time $(240 \mathrm{~min})$. Then temperature was optimized within the range of $120-270{ }^{\circ} \mathrm{C}$ at constant time $(240 \mathrm{~min})$ and within optimized proportion of reagents $\left(2.5 \mathrm{~mL}\left(\mathrm{HNO}_{3}\right), 1 \mathrm{~mL}\left(\mathrm{HClO}_{4}\right)\right.$ and $0.5 \mathrm{~mL}\left(\mathrm{H}_{2} \mathrm{O}_{2}\right)$. Lastly, the favorable time was optimized at constant optimized temperature $\left(210{ }^{\circ} \mathrm{C}\right)$ and constant proportion of reagents $\left(2.5 \mathrm{~mL}\left(\mathrm{HNO}_{3}\right), 1 \mathrm{~mL}\left(\mathrm{HClO}_{4}\right)\right.$ and $0.5 \mathrm{~mL}\left(\mathrm{H}_{2} \mathrm{O}_{2}\right)$. Finally, 2.5 $\mathrm{mL}\left(\mathrm{HNO}_{3}\right), 1 \mathrm{~mL}\left(\mathrm{HClO}_{4}\right)$ and $0.5 \mathrm{~mL}\left(\mathrm{H}_{2} \mathrm{O}_{2}\right)$ reagent proportion at $210{ }^{\circ} \mathrm{C}$ temperature for 140 min was selected for digestion of niger seed sample. 


\section{Recovery results}

The percentage of recoveries for the studied metals in niger seeds were found in the ranges of $90-107 \%$ (Table 3 ). These ranges fall in the acceptable range $[25,26]$. Therefore, this verifies that the optimized digestion procedures and instruments were valid for metal determinations in niger seed.

Table 3. Recovery test results for metals determination in niger seed.

\begin{tabular}{|c|c|c|c|c|}
\hline Metal & $\begin{array}{c}\text { Conc. in unspiked } \\
\text { sample }(\mu \mathrm{g} / \mathrm{g})\end{array}$ & $\begin{array}{c}\text { Amount added } \\
(\mu \mathrm{g} / \mathrm{g})\end{array}$ & $\begin{array}{c}\text { Conc. in spiked sample } \\
(\mu \mathrm{g} / \mathrm{g})\end{array}$ & Recovery (\%) \\
\hline $\mathrm{Na}$ & 430 & 86.0 & $509 \pm 3$ & $91 \pm 3$ \\
\hline $\mathrm{K}$ & 7640 & 1142 & $8760 \pm 4$ & $98 \pm 4$ \\
\hline $\mathrm{Ca}$ & 850 & 84.0 & $933 \pm 3$ & $99 \pm 3$ \\
\hline $\mathrm{Mg}$ & 4800 & 560 & $5333 \pm 6$ & $95 \pm 5$ \\
\hline $\mathrm{Mn}$ & 35.0 & 6.0 & $41.3 \pm 0.6$ & $105 \pm 1$ \\
\hline $\mathrm{Fe}$ & 253 & 28.0 & $280 \pm 5.0$ & $95 \pm 5$ \\
\hline $\mathrm{Cu}$ & 71.7 & 11.0 & $81.7 \pm 1.2$ & $91 \pm 1$ \\
\hline $\mathrm{Zn}$ & 64.0 & 7.0 & $71.5 \pm 1.1$ & $107 \pm 1$ \\
\hline $\mathrm{Cr}$ & 21.9 & 2.0 & $23.7 \pm 1.0$ & $90 \pm 1$ \\
\hline $\mathrm{Co}$ & 16.4 & 2.0 & $18.3 \pm 0.9$ & $95 \pm 1$ \\
\hline $\mathrm{Ni}$ & 29.6 & 7.0 & $37.0 \pm 0.8$ & $107 \pm 1$ \\
\hline $\mathrm{Cd}$ & 3.0 & 3.0 & $5.7 \pm 0.5$ & $90 \pm 1$ \\
\hline $\mathrm{Pb}$ & 17.0 & 4.0 & $20.7 \pm 0.5$ & $93 \pm 1$ \\
\hline
\end{tabular}

Conc. $=$ concentration.

\section{Distribution patterns of metals in niger seed samples}

The concentration of thirteen metals (major, trace, toxic) ( $\mathrm{Na}, \mathrm{K}, \mathrm{Ca}, \mathrm{Mg}, \mathrm{Mn}, \mathrm{Fe}, \mathrm{Cu}, \mathrm{Zn}, \mathrm{Cr}$, $\mathrm{Co}, \mathrm{Ni}, \mathrm{Cd}$, and $\mathrm{Pb}$ ) were determined in niger seed samples by flame atomic absorption spectrometry. The results are given in Table 4.

Nutrient interrelationships are complex, especially among the trace elements. A mineral cannot be affected without affecting at least two other minerals, each of which will then affect two others, etc. Mineral relationships can be compared to a series of intermeshing gears which are all connected, some directly and some indirectly. Two relationships exist among the trace elements, antagonistic and synergistic, which occur at two levels, metabolic and absorptive [27]. Therefore the concentration of major, trace and toxic metals in niger seed samples will be affected by the above factor. The distribution of metals are also affected by different factors; physical and chemical properties of the soil, application of natural (manure) and artificial fertilizers, increasing industrialization and associated pollution of the biosphere, climatic condition and rainfall of the place, and storage are the main factor for the mineral contents of the niger seed.

The niger seed samples collected from ten sample sites contained detectable major ( $\mathrm{Na}, \mathrm{K}$, $\mathrm{Ca}$, and $\mathrm{Mg}$ ) and trace $(\mathrm{Mn}, \mathrm{Fe}, \mathrm{Cu}, \mathrm{Zn}, \mathrm{Cr}, \mathrm{Co}, \mathrm{Ni}) . \mathrm{Pb}$ was detected in the samples from four sites (Kombolcha, Awi Zone, Debre Markos, and Mekelle) only and Cd was below detection in samples from all sites. The distribution of metal varies from site to site. The pattern of concentration of metal in niger seed collected from ten sites was decreased as $\mathrm{K}>\mathrm{Mg}>\mathrm{Ca}>$ $\mathrm{Na}>\mathrm{Fe}>\mathrm{Zn}>\mathrm{Cu}>\mathrm{Ni}>\mathrm{Mn}>\mathrm{Co}>\mathrm{Pb}>\mathrm{Cr}$. 
Table 4. Mean concentration ( $\mathrm{X} \pm \mathrm{SD}, \mathrm{n}=9, \mu \mathrm{g} / \mathrm{g}$ dry weight $)$ of metals in niger seed samples.

\begin{tabular}{|l|c|c|c|c|c|c|c|c|c|c|c|c|c|}
\hline Sample sites & \multicolumn{10}{|c|}{ Concentration $(\mu \mathrm{g} / \mathrm{g})^{\mathrm{a}}$} \\
& $\mathrm{Na}$ & $\mathrm{K}$ & $\mathrm{Ca}$ & $\mathrm{Mg}$ & $\mathrm{Mn}$ & $\mathrm{Fe}$ & $\mathrm{Cu}$ & $\mathrm{Zn}$ & $\mathrm{Cr}$ & $\mathrm{Co}$ & $\mathrm{Ni}$ & $\mathrm{Cd}$ & $\mathrm{Pb}$ \\
\hline Kombolcha & 425 & 7616 & 420 & 3660 & 26.2 & 139 & 55.1 & 32.9 & 7.50 & 10.4 & 32.4 & $\mathrm{ND}^{\mathrm{b}}$ & 19.3 \\
& \pm 26 & \pm 50 & \pm 11 & \pm 70 & \pm 0.4 & \pm 4.8 & \pm 2.2 & \pm 0.45 & \pm 0.8 & \pm 1.1 & \pm 1.1 & & \pm 1.8 \\
\hline Gondar & 436 & 8203 & 540 & 3576 & 19.0 & 33.1 & 19.8 & 43.8 & 7.80 & 25.1 & 13.6 & $\mathrm{ND}^{\mathrm{b}}$ & $\mathrm{ND}^{\mathrm{b}}$ \\
& \pm 22 & \pm 71 & \pm 12 & \pm 90 & \pm 0.6 & \pm 3.3 & \pm 1.5 & \pm 0.42 & \pm 0.8 & \pm 1.9 & \pm 1.1 & & \\
\hline Debre & 430 & 7063 & 680 & 2404 & 16.1 & 130 & 61.2 & 23.4 & 6.00 & 13.0 & 20.3 & $\mathrm{ND}^{\mathrm{b}}$ & $\mathrm{ND}^{\mathrm{b}}$ \\
Birhan & \pm 25 & \pm 56 & \pm 1 & \pm 30 & \pm 0.5 & \pm 4.0 & \pm 2.0 & \pm 0.36 & \pm 0.6 & \pm 1.4 & \pm 1.1 & & \\
\hline Awi Zone & 519 & 7823 & 350 & 4656 & 16.1 & 105 & 9.50 & 43.1 & 8.10 & 27.3 & 29.2 & $\mathrm{ND}^{\mathrm{b}}$ & 19.2 \\
& \pm 26 & \pm 68 & \pm 12 & \pm 130 & \pm 0.6 & \pm 3.2 & \pm 1.1 & \pm 0.47 & \pm 0.9 & \pm 1.6 & \pm 0.9 & & \pm 2.0 \\
\hline Debre & 736 & 7244 & 480 & 3593 & 23.2 & 158 & 16.6 & 35.1 & 7.00 & 19.2 & 26.5 & $\mathrm{ND}^{\mathrm{b}}$ & 16.9 \\
Markos & \pm 33 & \pm 162 & \pm 11 & \pm 70 & \pm 0.6 & \pm 4.2 & \pm 1.2 & \pm 0.40 & \pm 0.6 & \pm 1.2 & \pm 1.3 & & \pm 1.5 \\
\hline Jimma & 230 & 5594 & 380 & 2649 & 29.8 & 35.5 & 44.1 & 46.2 & 4.00 & 23.9 & 21.6 & $\mathrm{ND}^{\mathrm{b}}$ & $\mathrm{ND}^{\mathrm{b}}$ \\
& \pm 25 & \pm 39 & \pm 10 & \pm 80 & \pm 0.9 & \pm 3.3 & \pm 1.7 & \pm 0.52 & \pm 0.3 & \pm 2.8 & \pm 0.7 & & \\
\hline Wellega & 558 & 7710 & 340 & 3983 & 34.3 & 214 & 35.0 & 31.7 & 7.80 & 4.90 & 15.9 & $\mathrm{ND}^{\mathrm{b}}$ & $\mathrm{ND}^{\mathrm{b}}$ \\
& \pm 33 & \pm 83 & \pm 11 & \pm 50 & \pm 0.4 & \pm 3.3 & \pm 1.6 & \pm 0.45 & \pm 0.7 & \pm 0.3 & \pm 0.5 & & \\
\hline Alamata & 158 & 6852 & 520 & 3115 & 14.9 & 308 & 20.1 & 26.1 & 14.8 & 22.5 & 25.7 & $\mathrm{ND}^{\mathrm{b}}$ & $\mathrm{ND}^{\mathrm{b}}$ \\
& \pm 22 & \pm 86 & \pm 10 & \pm 50 & \pm 0.4 & \pm 4.0 & \pm 1.2 & \pm 0.34 & \pm 1.4 & \pm 2.1 & \pm 1.3 & & \\
\hline Mekelle & 214 & 6188 & 540 & 3837 & 13.4 & 31.6 & 37.3 & 37.9 & 5.80 & 15.9 & 13.0 & $\mathrm{ND}^{\mathrm{b}}$ & 15.5 \\
& \pm 25 & \pm 78 & \pm 35 & \pm 90 & \pm 0.5 & \pm 3.6 & \pm 2.0 & \pm 0.49 & \pm 0.5 & \pm 1.4 & \pm 0.7 & & \pm 1.6 \\
\hline Eretria & 408 & 7638 & 430 & 3432 & 29.2 & 369 & 26.6 & 35.5 & 16.8 & 12.5 & 25.3 & $\mathrm{ND}^{\mathrm{b}}$ & $\mathrm{ND}^{\mathrm{b}}$ \\
& \pm 22 & \pm 66 & \pm 11 & \pm 70 & \pm 0.4 & \pm 3.3 & \pm 1.6 & \pm 0.40 & \pm 1.4 & \pm 1.3 & \pm 1.1 & & \\
\hline
\end{tabular}

${ }^{\mathrm{a}}$ Mean concentration $\left(\mathrm{X} \pm \mathrm{SD}, \mathrm{n}=9, \mu \mathrm{g} / \mathrm{g}\right.$ dry weight). ${ }^{\mathrm{b}}$ Concentration of tested toxic metal below method detection limit $(\mathrm{Cd}<6 \mu \mathrm{g} / \mathrm{g}, \mathrm{Pb}<13.5 \mu \mathrm{g} / \mathrm{g})$.

Table 5 shows that the concentration (in $\mu \mathrm{g} / \mathrm{g}$ ) of $\mathrm{K}$ (5594-8203) is larger compared to other metal, Mg (2404-4656), Ca (340-680), Na (159-736), Fe (31.6-370), Zn (23.4-46.2), Cu (9.561.2), Ni (13.0-32.4), Mn (13.4-34.3), Co (4.9-27.3), Pb (15.5-19.3), and $\mathrm{Cr}(4.0-16.8)$ are decreasing order of the concentration. The comparison of metal concentrations in niger seed samples from different sites are shown in Figure 2.

Table 5. Mean and range of concentration of metals in niger seed samples.

\begin{tabular}{|l|c|c|}
\hline Metal & Mean concentration $(\mu \mathrm{g} / \mathrm{g})$ & Concentration range $(\mu \mathrm{g} / \mathrm{g})$ \\
\hline $\mathrm{Na}$ & 412 & $159-736$ \\
\hline $\mathrm{K}$ & 7193 & $5594-8203$ \\
\hline $\mathrm{Ca}$ & 468 & $340-680$ \\
\hline $\mathrm{Mg}$ & 3490 & $2404-4656$ \\
\hline $\mathrm{Mn}$ & 22.2 & $13.4-34.3$ \\
\hline $\mathrm{Fe}$ & 153 & $31.6-370$ \\
\hline $\mathrm{Cu}$ & 32.5 & $9.5-61.2$ \\
\hline $\mathrm{Zn}$ & 35.6 & $23.4-46.2$ \\
\hline $\mathrm{Cr}$ & 8.56 & $4.0-16.8$ \\
\hline $\mathrm{Co}$ & 17.5 & $4.9-27.3$ \\
\hline $\mathrm{Ni}$ & 22.4 & $13.0-32.4$ \\
\hline $\mathrm{Cd}$ & - & - \\
\hline $\mathrm{Pb}$ & 17.2 & $15.5-19.3$ \\
\hline
\end{tabular}

Sodium was present in larger amount in the sample from Debre Markos (736 \pm 33.1$)$ relative

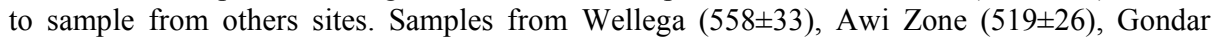
(436 \pm 22$)$, Debre Birhan (430 \pm 25$)$, Kombolcha (425 \pm 26$)$, Eretria (408 \pm 22$)$, Jimma (230 \pm 25$)$, Mekelle $(214 \pm 25)$ and Alamata $(158 \pm 22)$ were in decreasing order of Na concentration. The presence of large amount of $\mathrm{Na}$ in sample from Debre Markos may be due to the presence of 
water body around it. The absence of much amount of water in the surface and shortage of rainfall makes the sample from Mekelle and Alamata to contain small amount of $\mathrm{Na}$.

Niger seed sample from Gondar $(8203 \pm 70)$ had large amount $\mathrm{K}$ than samples from other sites. Samples from Awi zone (7823 \pm 68$)$, Wellega (7710 \pm 83$)$, Eretria (7638 \pm 67$)$, Kombolcha (7616 \pm 50$)$, Debre Markos (7244 \pm 162$)$, Debre Birhan (7063 \pm 56$)$, Alamata (6852 \pm 87$)$, Mekelle (6188 \pm 78$)$, and Jimma (5594 \pm 39$)$ were in decreasing order of K concentration.

Calcium was present in higher amount in niger seed sample from Debre Birhan $(680 \pm 11)$

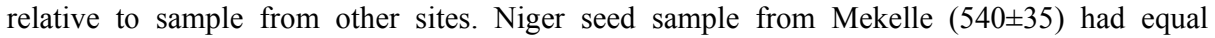
concentration with sample from Gondar. Samples from Alamata (520 \pm 10$)$, Debre Markos

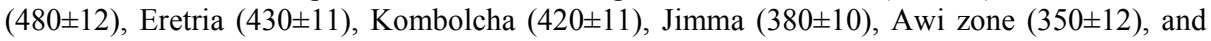
Wellega $(340 \pm 11)$ were in decreasing order of $\mathrm{Ca}$ concentration.
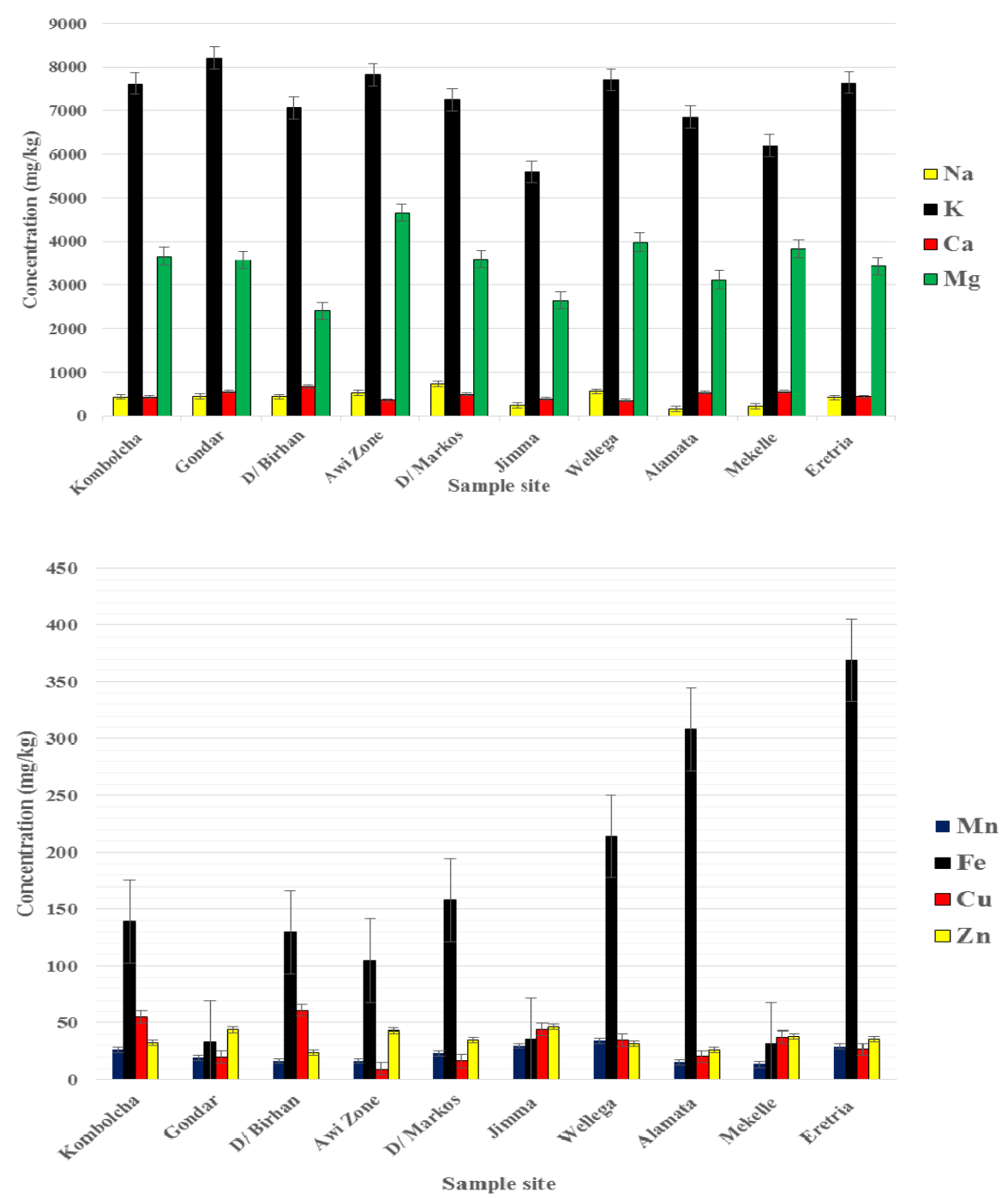

Bull. Chem. Soc. Ethiop. 2015, 29(3) 


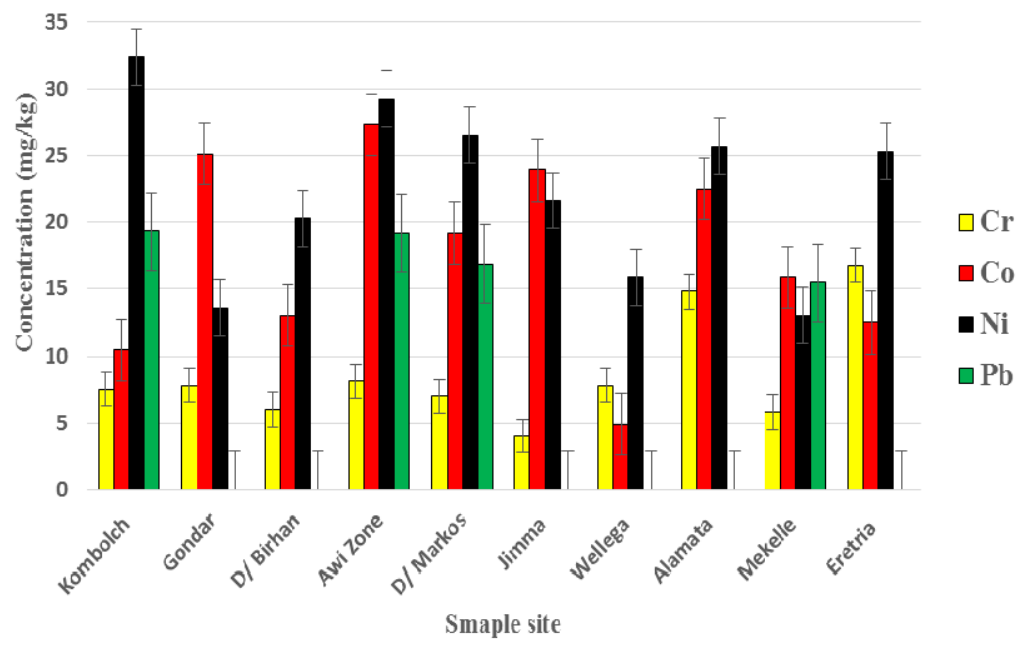

Figure 2. Distribution pattern of metals in niger seed sample.

Sample from Awi Zone (4656 \pm 130$)$ had larger Mg concentration than the sample from other

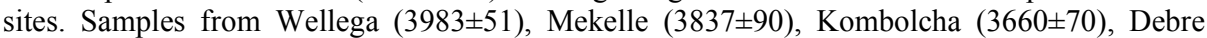
Markos (3593 \pm 71$)$, Gondar $(3576 \pm 90)$, Eretria (3432 \pm 71$)$, Alamata (3115 \pm 51$)$, Jimma $(2649 \pm 80)$, and Debre Birhan $(2404 \pm 30)$ were in decreasing order of Mg concentration. The concentration of $\mathrm{K}, \mathrm{Ca}$ and $\mathrm{Mg}$ in niger seed sample was higher in northern part of Ethiopia.

Manganese was present in larger amount in sample from Wellega (34.3 \pm 0.4$)$ relative to sample from other sites. Samples from Jimma (29.8 \pm 0.9$)$, Eretria (29.2 \pm 0.4$)$, Kombolcha (26.2 \pm 0.4$)$, Debre Markos (23.2 \pm 0.6$)$, Awi Zone (16.1 \pm 0.6$)$, Debre Birhan (16.1 \pm 0.5$)$, Alamata (14.9 \pm 0.4$)$, and Mekelle (13.4 \pm 0.5$)$ were in decreasing order of Mn concentration. Niger seed from Eretria (369 \pm 3.3$)$ had larger amount of $\mathrm{Fe}$ concentration relative to sample from other sites. Samples from Alamata (308 \pm 4.0$)$, Wellega (214 \pm 3.3$)$, Debre Markos (158 \pm 4.2$)$,

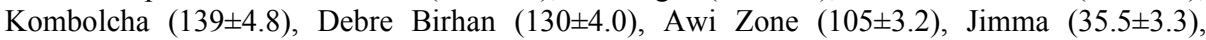
Gondar (33.1 \pm 3.3$)$, and Mekelle (31.6 \pm 3.6$)$ were in decreasing order of Fe concentration.

Copper was present in larger amount in sample from Debre Birhan (61.2 \pm 2.0$)$ relative to sample from other sites. Samples from Kombolcha (55.1 \pm 2.2$)$, Jimma (44.1 \pm 1.7$)$, Mekelle (37.3 \pm 2.0$)$, Wellega (35.0 \pm 1.6$)$, Eretria (26.6 \pm 1.6$)$, Alamata (20.1 \pm 1.2$)$, Gondar (19.8 \pm 1.5$)$, Debre Markos (16.6 \pm 1.2$)$, and Awi Zone $(9.50 \pm 1.1)$ were in decreasing order of $\mathrm{Cu}$ concentration.

Zinc was present larger amount in niger seed sample from Jimma $(46.2 \pm 0.52)$ relative to sample from other sites. Samples from Gondar (43.8 \pm 0.42$)$, Awi Zone (43.1 \pm 0.47$)$, Mekelle (37.9 \pm 0.49$)$, Eretria (35.5 \pm 0.40$)$, Debre Markos (35.1 \pm 0.40$)$, Kombolcha (32.9 \pm 0.45$)$, Wellega (31.7 \pm 0.45$)$, Alamata (26.1 \pm 0.34$)$, and Debre Birhan (23.4 \pm 0.36$)$ were in decreasing order of $\mathrm{Zn}$ concentration.

Niger seed sample from Eretria (16.8 \pm 1.4$)$ had larger amount of $\mathrm{Cr}$ concentration relative to

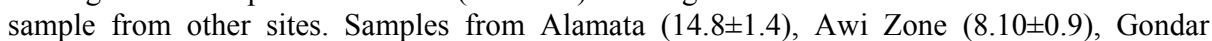

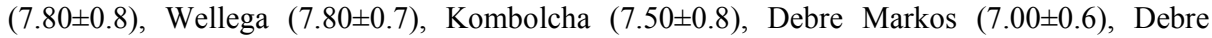

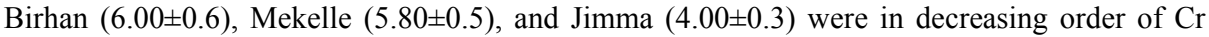
concentration. This variation may be due to the presence of tannery factories on some of the sample sites, which makes the concentration of $\mathrm{Cr}$ to be raised. 
Cobalt was present in larger amount in sample from Awi Zone $(27.3 \pm 1.6)$ when compare to

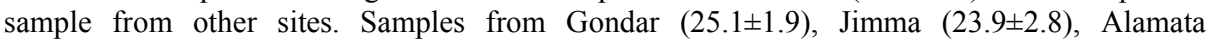

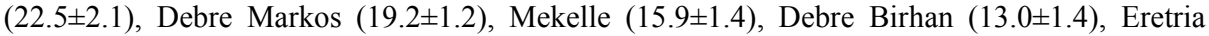
$(12.5 \pm 1.3)$, Kombolcha $(10.4 \pm 1.1)$, and Wellega $(4.90 \pm 0.3)$ were in decreasing order of Co concentration.

Nickel was present in larger concentration in sample from Kombolcha $(32.4 \pm 1.1)$ relative to the sample from other sites. Samples from Awi Zone (29.2 \pm 0.9$)$, Debre Markos (26.5 \pm 1.3$)$, Alamata (25.7 \pm 1.3 ), Eretria (25.3 \pm 1.1$)$, Jimma (21.6 \pm 0.7$)$, Debre Birhan (20.3 \pm 1.1$)$, Wellega $(15.9 \pm 0.5)$, Gondar (13.6 \pm 1.1$)$, and Mekelle $(13.0 \pm 0.7)$ were in decreasing order of $\mathrm{Ni}$ concentration.

Toxic metal was present in niger seed sample in very trace amount. Sample from some of sites were below detection limit. Cadmium was present below detection limit $(\mathrm{Cd}<6 \mu \mathrm{g} / \mathrm{g})$ in the sample from all sites.

Sample from Kombolcha (19.3 \pm 1.8$)$ had larger amount $\mathrm{Pb}$ concentration when compare to sample from other sites. Sample from Awi Zone (19.2 \pm 2.0$)$, Debre Markos (16.9 \pm 1.5$)$ and Mekelle (15.5 \pm 1.6$)$ were in decreasing order of $\mathrm{Pb}$ concentration. The remaining sample from sites (Gondar, Debre Birhan, Jimma, Wellega, Alamata and Eretria) were below detection limit $(\mathrm{Pb}<13.5 \mu \mathrm{g} / \mathrm{g})$. The presence of detectable $\mathrm{Pb}$ concentration samples from Kombolcha, Awi Zone, Debre Markos and Mekelle is due to the presence of factories that is related to dyes.

\section{Comparison of metal levels in this study (niger seed) with literatures values}

The concentrations of metals in plant mostly depend on the nutrient absorbing capacity of individual plant. Level of metals in plant also depend on metal content of the soil in which it grow, the accessibility of metal by plant or water soluble property of metal complex in the soil, rain fall level and climate condition.

Sodium is one of major element present in plant. The minimum sodium requirement of human is about $1,500 \mathrm{mg}$ each day. This is less than 1 teaspoon of table salt. The maximum recommended level of sodium intake is $2,300 \mathrm{mg}$ per day [28-30]. Sodium is present in oil seeds and differs with the seeds type. Sodium contents of oil seeds determined in different places are briefly discussed below. Niger seed $(412 \mu \mathrm{g} / \mathrm{g})$ (Ethiopia) in this study, linseed $(324 \mu \mathrm{g} / \mathrm{g}$ ) (Pakistan) [31] and sesame $(153 \mu \mathrm{g} / \mathrm{g})$ (Turkey) [32] were the Na content of dry weight of the seeds. Niger seeds relatively contain large amount of $\mathrm{Na}$ than the other seeds. Sodium in niger seed is higher (nearly $90 \mu \mathrm{g} / \mathrm{g}$ ) than linseed and it is also more than double of sesame. This indicates niger seeds are highly nutritious in $\mathrm{Na}$ and more salty than other oil seeds.

Plant requires potassium in large amount for growth and reproduction. The daily recommended allowance for potassium has been established $3500 \mathrm{mg}$ per day for adults (over 18 years) of both sexes [28-30]. The distribution of potassium in oil seeds is different. Niger seed $(7193 \mu \mathrm{g} / \mathrm{g})$ (Ethiopia) in this study, linseed (8263 $\mu \mathrm{g} / \mathrm{g}$ ) (Pakistan) [31] and sesame (5259 $\mu \mathrm{g} / \mathrm{g}$ ) (Turkey) [33] were content of $\mathrm{K}$ of the dry weight of the seeds. Niger seed contain intermediate amount of K. Potassium content of niger seeds is relatively smaller than linseed but some what larger than sesame. This indicates niger seed contain moderate amount of K.

Calcium is the major nutrient present in plant for production of new growing points and root tips. In the elementary composition of the human body, it ranks fifth after oxygen, carbon, hydrogen, and nitrogen, and it makes up $1.9 \%$ of the body by weight. The daily recommended allowance for calcium has been established $2000 \mathrm{mg}$ per day $[34,35]$. The distribution of calcium in oil seed differ with the type and place of oil seeds. Niger seed (468 $\mu \mathrm{g} / \mathrm{g}$ ) (Ethiopia) in this study, linseed $(2408 \mu \mathrm{g} / \mathrm{g})$ (Pakistan) [31] and sesame $(4154 \mu \mathrm{g} / \mathrm{g})$ (Congo-Brazzaville) [36] were Ca content of the dry weight of the seeds. Calcium concentration in niger seed is relatively much smaller than the other oil seeds. The other seeds (linseed and sesame) contain around 5-9 times $\mathrm{Ca}$ than niger seed. This indicates niger seed had poor calcium content relative to other oil seeds. 
Magnesium ion is the major nutrient present in plant as a critical cation and cofactor in numerous intracellular processes. The human body contains about $760 \mathrm{mg}$ of magnesium at birth, approximately $5 \mathrm{~g}$ at age $4-5$ months, and $25 \mathrm{~g}$ when adult [37]. The magnesium intake recommendation is $420 \mathrm{mg}$ for adult men. No exact figures have been given for other groups, but the weight-based corresponding value for women would be approximately $300 \mathrm{mg}$ a day [38]. The distribution of $\mathrm{Mg}$ in oil seeds is discussed below. Niger seed (3490 $\mu \mathrm{g} / \mathrm{g})$ (Ethiopia) in this study, linseed (4305 $\mu \mathrm{g} / \mathrm{g}$ ) (Pakistan) [31] and sesame (3499 $\mu \mathrm{g} / \mathrm{g}$ ) (Turkey) [33] were $\mathrm{Mg}$ content of the dry weight of the seeds. Niger seeds had larger amount of Mg content. Niger seeds have less $\mathrm{Mg}$ content than linseed, nearly equal to sesame. This indicates that niger seed is rich in $\mathrm{Mg}$ content.

Manganese is present in plant with trace amount for activation of enzymes [32]. Manganese is present in all tissues of the human body. The precise requirement has not been determined, 2.5 to $5.0 \mathrm{mg}$ per day has been estimated to constitute an adequate and safe intake [39]. The distribution of Mn differs in oil seeds. Niger seed $(22.2 \mu \mathrm{g} / \mathrm{g})$ (Ethiopia) in this study, linseed $(27.6 \mu \mathrm{g} / \mathrm{g}$ ) (Pakistan) [31] and sesame (34.6 $\mu \mathrm{g} / \mathrm{g})$ (Turkey) [33] were the Mn content of dry weight seeds. Niger seeds had larger Mn content. Niger seed had nearly similar content of Mn with linseed, smaller than sesame. This indicates that niger seed has intermediate amount of Mn content.

Iron is one of mineral which is present in the plant in trace amount for the formation of chlorophyll. Iron is a mineral that is found in every cell in the body. The recommended dietary allowance for iron for non-vegetarian pre-menopausal women is $18 \mathrm{mg} / \mathrm{day}$ and $14 \mathrm{mg} /$ day for vegetarian men. For non-vegetarian men and post-menopausal women is $8 \mathrm{mg} / \mathrm{day}$. The upper level of intake should not exceed $45 \mathrm{mg} /$ day [40]. Iron distributed in the oil seed plant evenly as follow. Niger seed $(153 \mu \mathrm{g} / \mathrm{g})$ (Ethiopia) in this study, linseed $(61.0 \mu \mathrm{g} / \mathrm{g})$ (Pakistan) [31], and sesame $(114 \mu \mathrm{g} / \mathrm{g})$ (Turkey) [33] were the Fe content of dry weight seeds. Niger seed contain largest amount of Fe concentration in comparison to the other oil seeds. Niger seed had larger Fe content than sesame and more than double of the linseed. This indicates niger seed is rich with Fe content.

Copper is trace element present in the plant as an enzyme activator. The distribution of $\mathrm{Cu}$ in oil seeds is discussed below as follow. Niger seed $(32.5 \mu \mathrm{g} / \mathrm{g}$ ) (Ethiopia) in this study, linseed $(19.6 \mu \mathrm{g} / \mathrm{g}$ ) (Pakistan) [31] and sesame $(21.5 \mu \mathrm{g} / \mathrm{g}$ ) (Turkey) [33] were the $\mathrm{Cu}$ content of dry weight of seeds. Copper is present in higher amount in niger seeds relative to other oil seeds. Copper content in niger seed is larger than that of linseed and nearly double content than sesame and sunflower. This indicates niger seed is rich in $\mathrm{Cu}$ content.

Zinc is an essential element for activation of enzymes, present in trace amount. Zinc is present in all body tissues and fluids. The recommended intake for human is $7-15 \mathrm{mg} /$ day [41]. Zinc distributed through plant differently and discussed below about the distribution of $\mathrm{Zn}$ in oil seeds. Niger seeds $(35.6 \mu \mathrm{g} / \mathrm{g})$ (Ethiopia) in this study, linseed (Pakistan) $(45.1 \mu \mathrm{g} / \mathrm{g})$ [31] and sesame $(88.7 \mu \mathrm{g} / \mathrm{g})$ (Turkey) [33] were the Zn content of dry weight seeds. Zinc is present in niger seeds with intermediate amount when compare to the other oil seeds. Niger seed had smaller $\mathrm{Zn}$ content than linseed but sesame had double $\mathrm{Zn}$ content than niger seed. This indicates the $\mathrm{Zn}$ content in niger seed is appreciable.

Chromium is one of the essential elements which is present in trace amount. The human body requires small amounts of it to function properly. On average, adults take in an estimated 60 micro gram of trivalent chromium every day with their food [42, 43]. Chromium is distributed in oil seeds differently as the individual plant and discussed below. Niger seed (8.56 $\mu \mathrm{g} / \mathrm{g}$ ) (Ethiopia) in this study and linseed $(<2 \mu \mathrm{g} / \mathrm{g}$ ) (Pakistan) [44] were the Cr content of dry weight seeds. Chromium is present in large amount in niger seed than that of linseed.

Cobalt is present in the plant in trace amount. Cobalt is an essential trace element as a part of vitamin $\mathrm{B}_{12}$, which is necessary for folate and fatty acid metabolism. Adults (over 15 years old) ingested around $7.5 \mu \mathrm{g}$ of Co per day and children (aged 3 to 14 years) ingested approximately 
$7.3 \mu \mathrm{g}$ of Co per day $[45,46]$. Distribution of Co is different in different plant and discussed as follow. Niger seed $(17.5 \mu \mathrm{g} / \mathrm{g}$ ) (Ethiopia) in this study and linseed (76 $\mu \mathrm{g} / \mathrm{g}$ ) (Pakistan) [44] were the Co content of dry weight seeds. This indicates niger seed is poor with Co content from linseed.

Nickel is a nutritionally essential trace metal for at least several animal species, microorganisms and plants. About $170 \mu \mathrm{g}$ of nickel is required in our food every day. Our daily intake of nickel from drinking water is only about $2 \mu \mathrm{g}$. We breathe in between 0.1 and $1 \mu \mathrm{g}$ nickel/day, excluding nickel in tobacco smoke [47, 48]. Nickel is present in plant in trace amount and distributed evenly in different plant. Nickel presents in niger seeds $(22.4 \mu \mathrm{g} / \mathrm{g})$ (Ethiopia) in this study and linseed (19 $\mu \mathrm{g} / \mathrm{g}$ ) (Pakistan) [35] of dry weight seeds. Nickel content in niger seed is almost similar with that of linseed.

Cadmium is one the toxic element that mostly present in ultra trace amount. The normal intake of cadmium (1-3 micrograms/day) does not appear to cause health problems [49]. Cadmium is present in oil seeds in very small amount and discussed below about $\mathrm{Cd}$ content of some oil seeds. Niger seed (below detection limit) (Ethiopia) in this study and linseed $(0.13$ $\mu \mathrm{g} / \mathrm{g}$ ) (Turkey) [50] were the Cd content of dry weight seeds. Niger seed had much smaller amount of $\mathrm{Cd}$ than linseed and indicates that it is free from $\mathrm{Cd}$ toxicity.

Lead is present in plant in very trace level and it is toxic for the plant. Adult human's body contains approximately $200 \mathrm{mg}$ of lead [51]. Lead is presents in the oil seeds differently. Niger seeds $(17.2 \mu \mathrm{g} / \mathrm{g})$ (Ethiopia) in this study and linseed $(1.7 \mu \mathrm{g} / \mathrm{g}$ ) (Pakistan) [44] were the $\mathrm{Pb}$ content of dry weight seeds. Niger seed had large $\mathrm{Pb}$ relative to linseed.

\section{Pearson correlation of metals in niger seed}

There are several ways that this correlation coefficient can be found. In this study the Pearson's product moment correlation coefficient were used due to fast, easy to calculate and easy of interpreting the output are the main reasons.

Table 6. Correlation matrices for metals in niger seed samples.

\begin{tabular}{|l|l|l|l|l|l|l|l|l|l|l|l|}
\hline & $\mathrm{Na}$ & $\mathrm{K}$ & $\mathrm{Ca}$ & $\mathrm{Mg}$ & $\mathrm{Mn}$ & $\mathrm{Fe}$ & $\mathrm{Cu}$ & $\mathrm{Zn}$ & $\mathrm{Cr}$ & $\mathrm{Co}$ & $\mathrm{Ni}$ \\
\hline $\mathrm{Na}$ & 1.000 & & & & & & & & & & \\
\hline $\mathrm{K}$ & 0.604 & 1.000 & & & & & & & & & \\
\hline $\mathrm{Ca}$ & -0.207 & -0.107 & 1.000 & & & & & & & & \\
\hline $\mathrm{Mg}$ & 0.386 & 0.511 & -0.568 & 1.000 & & & & & & & \\
\hline $\mathrm{Mn}$ & 0.302 & 0.076 & -0.643 & -0.10 & 1.000 & & & & & & \\
\hline $\mathrm{Fe}$ & 0.039 & 0.277 & -0.122 & -0.039 & 0.274 & 1.000 & & & & & \\
\hline $\mathrm{Cu}$ & -0.250 & -0.347 & 0.329 & -0.577 & 0.193 & -0.172 & 1.000 & & & & \\
\hline $\mathrm{Zn}$ & 0.004 & -0.086 & -0.450 & 0.415 & 0.132 & -0.599 & -0.352 & 1.000 & & & \\
\hline $\mathrm{Cr}$ & -0.155 & 0.342 & -0.052 & 0.153 & 0.082 & 0.914 & -0.361 & -0.218 & 1.000 & & \\
\hline $\mathrm{Co}$ & -0.017 & -0.144 & -0.074 & 0.109 & -0.468 & -0.355 & -0.542 & 0.192 & -0.011 & 1.000 & \\
\hline $\mathrm{Ni}$ & 0.205 & 0.160 & -0.322 & 0.158 & 0.121 & 0.394 & -0.049 & -0.063 & 0.371 & 0.145 & 1.000 \\
\hline
\end{tabular}

${ }^{*}$ Correlations based on the probability levels at 0.05 .

Table 6 showed that strong positive correlation was obtained from $\mathrm{Cr}$ with $\mathrm{Fe}$ due to highly synergetic relationship between them. $\mathrm{K}$ with $\mathrm{Na}$ and $\mathrm{Mg}$ with $\mathrm{K}$ have moderate positive correlation due to synergism between the elements occurs largely on a metabolic level. $\mathrm{Mg}$ with $\mathrm{Ca}, \mathrm{Mn}$ with $\mathrm{Ca}, \mathrm{Cu}$ with $\mathrm{Mg}, \mathrm{Zn}$ with $\mathrm{Fe}$ and $\mathrm{Co}$ with $\mathrm{Cu}$ have moderate negative correlation due to antagonisms relationship between the element occurs on a metabolic level. Positive and weak relation occurred between $\mathrm{Mg}$ with $\mathrm{Na}, \mathrm{Mn}$ with $\mathrm{Na}$, Fe with $\mathrm{K}$, Fe with $\mathrm{Mn}, \mathrm{Cu}$ with $\mathrm{Ca}$, $\mathrm{Zn}$ with $\mathrm{Mg}$, Cr with $\mathrm{K}$, Ni with $\mathrm{Fe}$ and $\mathrm{Ni}$ with $\mathrm{Cr}$. $\mathrm{Cu}$ with $\mathrm{Na}, \mathrm{Cu}$ with $\mathrm{K}$, $\mathrm{Zn}$ with $\mathrm{Ca}, \mathrm{Zn}$ with $\mathrm{Cu}, \mathrm{Cr}$ with $\mathrm{Cu}$, Co with $\mathrm{Mn}$, Co with $\mathrm{Fe}$ and $\mathrm{Ni}$ with $\mathrm{Ca}$ have weak negative relationship 
between the elements. $\mathrm{Ca}$ with $\mathrm{Na}, \mathrm{Ca}$ with $\mathrm{K}, \mathrm{Mn}$ with $\mathrm{K}, \mathrm{Mn}$ with $\mathrm{Mg}$, $\mathrm{Fe}$ with $\mathrm{Na}, \mathrm{Fe}$ with $\mathrm{Ca}, \mathrm{Fe}$ with $\mathrm{Mg}, \mathrm{Cu}$ with $\mathrm{Mn}, \mathrm{Cu}$ with $\mathrm{Fe}, \mathrm{Zn}$ with $\mathrm{Na}, \mathrm{Zn}$ with $\mathrm{K}, \mathrm{Zn}$ with $\mathrm{Mn}, \mathrm{Cr}$ with $\mathrm{Na}, \mathrm{Cr}$ with $\mathrm{Ca}, \mathrm{Cr}$ with $\mathrm{Mg}, \mathrm{Cr}$ with $\mathrm{Mn}, \mathrm{Cr}$ with $\mathrm{Zn}$, Co with $\mathrm{Na}$, Co with $\mathrm{K}$, Co with $\mathrm{Ca}$, Co with $\mathrm{Mg}$, Co with $\mathrm{Zn}$, Co with $\mathrm{Cr}$, Ni with $\mathrm{Na}$, Ni with $\mathrm{K}$, Ni with $\mathrm{Mg}$, Ni with $\mathrm{Mn}$, Ni with $\mathrm{Cu}, \mathrm{Ni}$ with $\mathrm{Zn}$ and $\mathrm{Ni}$ with Co have no linear relationship.

\section{Analysis of variance (ANOVA)}

In this study niger seeds were collected from ten different sites randomly. Each sample was mixed to be homogenized and represent the sample site. Niger seed was dried, ground, digested and diluted before analyzed. During all the steps random error may be introduced in each measurement or triplicate analysis. Difference in the results happened inter-sites and intra-sites. Therefore the results that are determined need to be checked by different statistical data analysis methods whether there is significant difference between the result or not. To decide whether the result has significant difference or not, analysis of variance (ANOVA) is compatible.

There was a significant difference $(\mathrm{p} \geq 0.05)$ in $\mathrm{Na}$ concentration between Kombolcha, Gondar, Debre Birhan, Awi Zone, Debre Markos, Jimma, Wellega, Alamata, Mekelle, and Eritrea Niger seeds samples. Similarly, there was significant difference $(p \geq 0.05)$ was observed in $\mathrm{K}, \mathrm{Ca}, \mathrm{Mg}, \mathrm{Mn}, \mathrm{Fe}, \mathrm{Cu}, \mathrm{Zn}, \mathrm{Cr}, \mathrm{Co}$ and $\mathrm{Ni}$ between the sites, such as Kombolcha, Gondar, Debre Birhan, Awi Zone, Debre Markos, Jimma, Wellega, Alamata, Mekelle, and Eritrea. The results indicated that there was inter-sites variation in mean concentration of metals, such as $\mathrm{Na}$, $\mathrm{K}, \mathrm{Ca}, \mathrm{Mg}, \mathrm{Mn}, \mathrm{Fe}, \mathrm{Cu}, \mathrm{Zn}, \mathrm{Cr}, \mathrm{Co}$ and $\mathrm{Ni}$. The presence of significance difference between the sites may be due to the presence different geographical distribution, rainfall, soil composition, and harvesting and storing methods.

There was no significant difference $(\mathrm{p} \geq 0.05)$ in $\mathrm{Pb}$ concentration between Kombolcha, Awi Zone, Debre Markos and Mekelle niger seeds samples. This indicated that there was no intersites variability in mean concentration of $\mathrm{Pb}$ in niger seeds sample. The absence of significance differences $(\mathrm{p} \geq 0.05)$ between the sites may be due to the similarity of $\mathrm{Pb}$ pollution of the soil and water by different factories.

\section{CONCLUSION}

In this study the levels of major mineral elements ( $\mathrm{Na}, \mathrm{K}, \mathrm{Ca}$ and $\mathrm{Mg}$ ), trace $(\mathrm{Mn}, \mathrm{Fe}, \mathrm{Cu}, \mathrm{Zn}$, $\mathrm{Cr}, \mathrm{Co}, \mathrm{Ni})$, and toxic $(\mathrm{Cd}, \mathrm{Pb})$ metals were determined in the niger seed which is produced in major parts of Ethiopia and Eritrea. The optimum reagent, temperature and time were identified for digestion and determination of the level of metals in niger seed. The efficiency of sample preparation and digestion was assessed by recovery experiment. The optimized wet digestion method for niger seeds was found efficient for all the metals and had good recovery results $(100 \pm 10)$.

The levels of major ( $\mathrm{Na}, \mathrm{K}, \mathrm{Ca}$ and $\mathrm{Mg}$ ), trace $(\mathrm{Mn}, \mathrm{Fe}, \mathrm{Cu}, \mathrm{Zn}, \mathrm{Cr}, \mathrm{Co}, \mathrm{Ni})$, and toxic $(\mathrm{Cd}$, $\mathrm{Pb})$ metals were found in niger seed in the order of abundance: $\mathrm{K}(5594-8203 \mu \mathrm{g} / \mathrm{g})>\mathrm{Mg}$ $(2404-4656 \mu \mathrm{g} / \mathrm{g})>\mathrm{Ca}(340-680 \mu \mathrm{g} / \mathrm{g})>\mathrm{Na}(159-736 \mu \mathrm{g} / \mathrm{g})>\mathrm{Fe}(31.6-370 \mu \mathrm{g} / \mathrm{g})>\mathrm{Zn}(23.4-$ $46.2 \mu \mathrm{g} / \mathrm{g})>\mathrm{Pb}(15.5-19.3 \mu \mathrm{g} / \mathrm{g})>\mathrm{Mn}(13.4-34.3 \mu \mathrm{g} / \mathrm{g})>\mathrm{Ni}(13.0-32.4 \mu \mathrm{g} / \mathrm{g})>\mathrm{Cu}(9.5-61.2$ $\mu \mathrm{g} / \mathrm{g})>\mathrm{Co}(4.9-27.3 \mu \mathrm{g} / \mathrm{g})$ and $\mathrm{Cr}(4.0-16.8 \mu \mathrm{g} / \mathrm{g})$. Pb was detected only in samples from Kombolcha, Awi Zone, Debre Markos and Mekelle sites but not in the samples from other sites, such as Gondar, Debre Birhan, Jimma, Wellega, Alamata and Eretria. Cd was not detected in samples from all sites. Niger seed is a good source of essential metals and free from toxic metals and hence safe for daily human consumption. Niger seed has comparable concentration of metal with other oil seeds. 


\section{ACKNOWLEDGEMENTS}

The authors express their gratitude to the Department of Chemistry, Addis Ababa University, Ethiopia, for providing the laboratory facilities. The first author would like to thankful to the Department of Chemistry, Debre Berhan University, Ethiopia, for sponsoring his study.

\section{REFERENCES}

1. Wijnands, J.; Biersteker, J.; Hiel; Oilseeds business opportunities in Ethiopia, Agriculture, nature and food quality, 2007. Available at www.lei.wur.n1/NR/.../070723OilseedsbusinessEthiopiaJW.pdf. Accessed on January 28, 2012.

2. Bhagya, S.; Shamanthaka Sastry, M.C. The Reference in Scientific Document Supply 2003, 36, 703.

3. Naik, P.M.; Murthy, H.N. Polish Acad. Sci. 2009, 32, 75.

4. Naik, P.M.; Murthy, H.N. Afr. J. Biotechnol. 2009, 8, 4459.

5. Getinet, A.; Sharma, S.M. Gaterslebe/International Plant Genetic Resources Institute 1996, 5,1 .

6. Chavan, V.M. Niger and Safflower, Indian Central Oilseeds Committee: Hyderabad; 1961, pp 1-53.

7. Ramadan, M.F.; Mörsel, J.T. Czech J. Food Sci. 2002, 20, 98.

8. Abebe, M.; Yermanos, D.M.; Bingham, F.T. Afr. J. Agric. Sci. 1978, 5, 55.

9. Geleta, M.; Stymne, S.; Bryngelsson, T. J. Food Comp. Anal. 2011, 24, 995.

10. Vles, R.O.; Gottenbos, J.J. Nutritional Characteristics and Food Uses of Vegetable Oils, in Oil Crops of the World, McGraw Hill: New York; 1989.

11. Dutta, P.C.; Helmersson, S.; Eshetu, K.; Getinet, A.; Appelqvist, L.A. J. Am. Oil Chem. Soc. 1994, 71, 839 .

12. Nasirullah, K.; Mallika, T.; Rajalakshmi, S.; Pashupathi, K.S.; Ankaiah, K.N.; Vibhakar, S.; Krishnamurthy, M.N.; Nagaraja, K.V.; Kapur, O.P. J. Food Sci. Technol. 1982, 19, 147.

13. Seegeler, C.J.P. Oil Plants in Ethiopia, Their Taxonomy and Agricultural Significance, Agriculture Research Report 921, Centre for Agricultural Publication and Documentation: Wageningen; 1983.

14. Almaw, G.; Teklewold, A. Plant Breeding 1995, 114, 375.

15. Derbie, A.; Chandravanshi, B.S. Biol. Trace Elem. Res. 2011, 141, 317.

16. Debebe, A.; Chandravanshi, B.S.; Wondimu, T. SINET: Ethiop. J. Sci. 2012, 35, 71.

17. Kitata, R.B.; Chandravanshi, B.S. Bull. Chem. Soc. Ethiop. 2012, $26,27$.

18. Weldegebriel, Y.; Chandravanshi, B.S.; Wondimu, T. Ecotoxicol. Environ. Saf. 2012, 77, 57.

19. Gebre, A.; Chandravanshi, B.S. Bull. Chem. Soc. Ethiop. 2012, 26, 329.

20. Shegro, A.; Shargie, N.G.; van Biljon, A.; Labuschagne, M.T. J. Crop Sci. Biotech. 2012, $15,275$.

21. Aregahegn, A.; Chandravanshi, B.S.; Atlabachew, M. Acta Hort. (ISHS) 2013, 979, 117.

22. Aregahegn, A.; Chandravanshi, B.S.; Atlabachew, M. Afr. J. Food Agric. Nutr. Dev. 2013, 13,7870 .

23. Duman, E.; Özcan, M.M. Environ. Monit. Assess. 2014, 186, 239.

24. Mekebo, D.; Chandravanshi, B.S. Bull. Chem. Soc. Ethiop. 2014, 28, 349.

25. Harris, D.C. Quantitative Chemical Analysis, 4th ed., Freeman and Company: New York; 1982.

26. Christian, G.D. Analytical Chemistry, 2nd ed., John Wiley and Sons: New York; 2004.

27. David, L.; Watts, D.C. J. Orthomol. Med. 1990, 5, 11. 
28. Institute of Medicine Dietary Reference Intakes for Water, Potassium, Sodium Chloride and Sulfate, National Academies Press: Washington DC; 2004.

29. Anderson, J.; Young, L.; Long, E.; Prior, S. Colo. St. Ex. St. Bull. 1996, 9, 354.

30. Whitney, E.N.; Rolfes, S.R. Understanding Nutrition, 10th ed.; CA: Thomson/Wadsworth Publishing Company: Belmont; 2005.

31. Hussain, S.; Anjum, F.M.; Butt, M.S.; Sheikh, M.A. Sarhad J. Agric. 2008, 24, 649.

32. Millaleo, R.; Reyes-Diaz, M.; Ivanov, A.G.; Mora, M.L. Alberdi, M. J. Soil Sci. Plant Nutr. 2010, 10, 4 .

33. Elleuch, M.; Besbes, S.; Roiseux, O.; Blecker, C.; Attia, H. Food Chem. 2007, 103, 641.

34. Nordin, B.E.C. Nutritional Considerations. Calcium, Phosphate and Magnesium Metabolism in Nordin, B.E.C. (Ed.), Churchill Livingstone: Edinburgh; 1976; p 1-35.

35. Houtkooper, L.; Farrell, .V.A. Calcium Supplement Guidelines, University of Arizona, 2011, p 1-4. Available at http://ag.arizona.edu/pubs/\%20health/az1042.pdf. Accesses on December 17, 2011.

36. Nzikou, J.M.; Matos, L.; Bouanga-Kalou, G.; Ndangui, C.B.; Pambou-Tobi, N.P.G.; Kimbonguila, A.; Silou, Th.; Linder, M.; Desobry, S. Adv. J. Food Sci. Technol. 2009, 1, 6.

37. McCarthy, J.T.; Kumar, R. Divalent Cation Metabolism: Magnesium. Available at www.kidneyatlas.org/book1/adk1_04.pdf. Accesses on December 19, 2011.

38. Karppanen, H.; Karppanen, P.; Mervaala, E. J. Hum. Hypertens 2005, 19, S10.

39. Tucker, M.R. Essential Plant Nutrients: Their Presence in North Carolina Soils and Role in Plant Nutrition, NCADA and CS Miscellaneous Publication, North Carolina Department of Agriculture and Consumer Service: Carolina; 1999; pp 1-12.

40. Bowes, D.P.; Church, N. Bowes and Church's Food Values of Portions Commonly Used, 17th ed.; JB Lipincott: Philadelphia; 1998.

41. Scientific Committee on Food Opinion of the Scientific Committee on Food on the revision of reference values for nutrition labeling, Scientific Committee on Food, 2003. Available at http://europa.eu.int/comm/food/fs/sc/scf/index_en.html. Accesses on December 22, 2011.

42. Jeejeebhoy, K.N.; Chu, R.C.; Marliss, E.B.; Greenberg, G.R.; Bruce-Robertson, A. Am. J. Clin. Nutr. 1977, 30, 531 .

43. Freund, H.; Atamian, S.; Fischer, J.E. J. Am. Med. Assoc. 1979, 241, 496.

44. Iftikar, A.; Mohammed, A.H.; Raziya, N.; Mohammed, S.J.; Muhammed, S.Z. J. Chem. Soc. Pak. 2008, 30, 400.

45. European Food Safety Authority Assessment of the safety of cobalt(II) chloride hexahydrate added for nutritional purposes as a source of cobalt in food supplements and the bioavailability of cobalt from this source, Statement of the Scientific Panel on Additives and Nutrient Sources added to Food (ANS), European Food Safety Authority: Brussels; 2009, 1066, pp 1-8.

46. Cobalt in Food, 2006. Available at www.thecdi.com. Accesses on December 28, 2011

47. Cempel, M.; Nikel, G. Pol. J. Environ. Stud. 2006, 15, 375.

48. World Health Organization Nickel in Drinking-Water. Background Document for Development Of WHO Guidelines for drinking-water quality, World Health Organization: Geneva; 2005.

49. Cadmium Wisconsin Department of Health and Family Services Division of Public Health with funds from the Agency for Toxic Substances and Disease Registry, Public Health Service, U.S. Department of Health and Human Services: Washington DC; Revised 12/2000. Available at http://dhfs.wisconsin.gov/eh. Accessed on December 28, 2011.

50. Ozkutlu, F.; Kara, S.M.; Sekeroglu, N. Acta Hort. (ISHS) 2007, 756, 321.

51. Rabinowitz, M.B.; Wetherill, G.W.; Kopple, J.D. J. Clin. Invest. 1976, 58, 260. 